\title{
Lanthanum( $(\mathbb{X})$-amino Acid Chelate Mitigates Copper(区) Stress in Rice (Oryza Sativa)
}

Jiajia Chen ( $\nabla$ njucjj@126.com )

Suzhou University of Science and Technology https://orcid.org/0000-0003-3659-0658

\section{Yuqing Zhong}

Suzhou University of Science and Technology

\section{Research Article}

Keywords: Lanthanum, Rare earth, Copper, Amino acid, Chelate, Rice (Oryza sativa)

Posted Date: May 17th, 2021

DOI: https://doi.org/10.21203/rs.3.rs-499369/v1

License: (c) (i) This work is licensed under a Creative Commons Attribution 4.0 International License. Read Full License 

sativa)

${ }^{\text {a }}$ School of Chemistry and Life Sciences, Suzhou University of Science and Technology, No.1 Kerui 5 Road, Suzhou 215011, China.

6

$7 \quad *$ Corresponding author at: School of Chemistry and Life Sciences, Suzhou University of Science and 8 Technology, 215011 Jiajia Chen, Suzhou, China.

$9 \quad$ E-mail address: njucjj@126.com.

10 Tel: 86-13912634686

11 Fax: 86-512-68418438 


\section{Abstract}

14 Lanthanum (La(III)) is known to alleviate heavy metal stress. However, the bioavailability of inorganic $\mathrm{La}(\mathrm{III})$ is limited due to easy oxidization and low absorption. This study synthesized and characterized the lanthanum(III)-amino acid chelate (La(III)-AA) from soybean protein isolate (SPI) hydrolysates. Maximum chelating rate $(94.95 \%)$ was obtained at mole ratio $1: 1.5, \mathrm{pH} 8.0,50^{\circ} \mathrm{C}$ and $5 \mathrm{~h}$. Glu, Asp and Pro represent the primary La(III)-binding ligands. UV-vis and FTIR demonstrated that amino nitrogen and carboxyl oxygen participate in metal-ligand recognition. Scanning and Transmission electron microscopy showed that $\mathrm{La}(\mathrm{III})$ chelates with amino acids in a core-shell structure of uniform size. Based on this, putative chemical structure of $\mathrm{La}(\mathrm{III})$-AA was suggested. La-AA outperforms inorganic La salts in growth promotion and $\mathrm{Cu}$ detoxification. This study provides a novel $\mathrm{La}$ (III)-based candidate for crop protection and advances our knowledge of rare earth-induced amelioration in heavy metal stress.

Keywords Lanthanum; Rare earth; Copper; Amino acid; Chelate; Rice (Oryza sativa) 


\section{Introduction}

With the growing concern on the use of the rare earth elements (REE) in agriculture, there are increasing evidences that REEs can protect plants against abiotic stress, such as salinity stress, cold stress and heavy metal stress (Gao et al. 2018, Habibi 2017, Lin et al. 2012). Lanthanum (La(III)) is a rare earth element that plays an important role in regulating the growth and development of plants. La(III) has positive effects on seed germination, reactive oxygen species regulation and photosynthesis (Liu et al. 2016a, Wang et al. 2014, Wen et al. 2011). La(III) at proper concentrations was confirmed to increase the Cdinduced activities of ascorbate peroxidase, dehydroascorbate reductase, glutathione reductase, Lgalactono-1,4-lactone dehydrogenase, and $\gamma$-glutamylcysteine synthetase to improve the Cd tolerance of maize (Dai et al. 2017). A certain concentration of $\mathrm{La}(\mathrm{III})$ could also alleviate the adverse effects of salt stress on soybeans, promote its growth, enhance antioxidant enzyme activity and reduce the accumulation of malondialdehyde (Zhao et al. 2014). The same result was proven in tomato (Huang \&Shan 2018). However, REEs are easily immobilized by soil due to the formation of insoluble substance with phosphate ion in soil, therefore the effectiveness of REE is reduced and environmental pollution may be caused. If the inorganic REE can be converted into organic chelate, the disadvantages of single REE such as easy oxidation, moisture absorption and low absorption rate can be overcome.

Numerous investigations about complexes and chelates of amino acids and metal have been described in the literature (Megias et al. 2007, Pal et al. 2019). D Leibler et al. generated the salicylaldehyde copper amino acid (Sal $\mathrm{Cu} \mathrm{AA}$ ) complexes which were found to bind protein molecules as IMAC resins (Leibler et al. 1996). In addition, it has been reported that glutamic acid as a primary ligand could form with copper(II) (Neuman et al. 2012), nickel(II) (Perez et al. 2017), cobalt(II) (Cheng et al. 2007), and zinc(II) (Dong et al. 2016) metals to make the new metal mixed-ligand complexes.

Soybean protein is a cost-effective resource to produce mixed amino acids in large quantities (Rizzo \&Baroni 2018). It can release abundant active peptides after enzymatic hydrolysis, and the amino acid and nutritional value are almost completely retained (Friedman \&Brandon 2001, Jin et al. 2000). Moreover, it has been reported that soy protein hydrolysate has the ability of binding calcium and can be used as a raw material for calcium supplements (Bao et al. 2007). Thus, many studies have been performed to generate health products e.g., calcium supplements with soybean protein hydrolysates. However, the chelation of soy protein hydrolysate and $\mathrm{La}(\mathrm{III})$ has rarely been reported and its effects on plants remain largely unknown. Therefore, it is interesting to know whether soybean protein produced 
high $\mathrm{La}(\mathrm{III})$-binding amino acids and to determine the binding mechanism of $\mathrm{La}(\mathrm{III})$ and amino acids.

This study produced a novel Lanthanum(III)-amino acid chelate (La(III)-AA) from enzymatic hydrolysis of soybean protein. Multiple analytical techniques were used with the aim of investigating the metal-ligand recognition processes. The findings would be of significance in utilizing soybean protein to produce $\mathrm{La}(\mathrm{III})$-AA and open up the possibility of further application of $\mathrm{La}(\mathrm{III})$-AA chelates in plant growth regulation.

\section{Material and methods}

\section{Preparation of SPI hydrolysates}

SPI was dissolved in deionized water at substrate concentration of $10 \%(\mathrm{wt} / \mathrm{vol})$. The solutions were hydrolyzed with serine protease under the following conditions: the enzyme dose was $10 \%$ (wt/wt, defined as enzyme mass/substrate mass $\mathrm{x} 100 \%$ ), $\mathrm{pH}$ value was 8.0 and temperature was $60{ }^{\circ} \mathrm{C}$. The hydrolysis process was carried out in a reactor equipped with a stirrer and temperature controller. The solution was reacted for $5 \mathrm{~h}$ and immediately heated in $90{ }^{\circ} \mathrm{C}$ water bath for 15 min to inactivate the proteases. After cooling to room temperature, the enzymatic hydrolysates were centrifuged at $10000 \mathrm{rpm}$ for $10 \mathrm{~min}$ at $4{ }^{\circ} \mathrm{C}$ to remove the fiber and other suspended solids.

\section{Degree of hydrolysis}

The degree of hydrolysis (DH) was calculated by the pH-stat titration method (Mirzakhani et al. 2018). The specific method as follows: at the beginning of hydrolysis, the $\mathrm{pH}$ value was adjusted to 8.0 with 1 $\mathrm{mol} / \mathrm{L} \mathrm{HCl}$ and kept by $1 \mathrm{~mol} / \mathrm{L} \mathrm{NaOH}$ during the reaction. The amount of $\mathrm{NaOH}$ used was recorded and the DH was calculated according to the following formula.

$$
\mathrm{DH}=\frac{B \times N_{b}}{\alpha \times m \times h_{\text {tot }}} \times 100
$$

where $\mathrm{B}$ is the amount of $\mathrm{NaOH}$ consumed (milliliters). $\mathrm{N}_{\mathrm{b}}$ is the molarity of $\mathrm{NaOH}(\mathrm{mol} / \mathrm{L}), \mathrm{m}$ is the mass (grams) of protein, the total number of peptide bonds ( $\left.\mathrm{h}_{\mathrm{tot}}\right)$ in SPI was assumed to be $7.75 \mathrm{mequiv} / \mathrm{g}$ and $\alpha$ is the average degree of dissociation of the $\alpha-\mathrm{NH}_{2}$ groups released during hydrolysis: $\alpha=\frac{10^{p H-p K}}{\left(1+10^{p H-p K}\right)}$, where $\mathrm{pH}$ and $\mathrm{pK}$ are the values at which the proteolysis was conducted.

\section{Preparation of mixed amino acids}

The solutions were decolorized with activated charcoal under the following conditions: the activated charcoal dose was $1 \mathrm{~g} / 100 \mathrm{ml}, \mathrm{pH}$ value was 3.0 and temperature was $80^{\circ} \mathrm{C}$. The solution was filtered to remove insoluble and concentrated to $1 / 3$ to $1 / 2$ volume by the rotary evaporator. Double volume absolute 
ethanol was added to the solution. The solution was put in the refrigerator $\left(0-4{ }^{\circ} \mathrm{C}\right)$ overnight. The insoluble was precipitated and removed by centrifugation at $10000 \mathrm{rpm}$ for $10 \mathrm{~min}$ at $4{ }^{\circ} \mathrm{C}$. The supernatant was purified by 732 cation resin, loaded onto the column at a speed of $2 \mathrm{BV} / \mathrm{h}$ and eluted by $3 \%$ ammonia water. The eluate was collected for concentration and crystallization, and then amino acid crystals were obtained.

Before and after decolorization, $5 \mathrm{~mL}$ solution was dilute to $25 \mathrm{~mL}$, and the absorbance was measured at $400 \mathrm{~nm}$ with enzyme-labeled instrument (TECAN F50, Infinite, Switzerland) The decolorization rate was calculated as follows:

$$
\text { decolorization rate }(\%)=\frac{A_{0}-A_{1}}{A_{0}} \times 100
$$

where $A_{0}$ is the absorbance of solution before decolorization, $A_{1}$ is the absorbance of solution after decolorization.

\section{Preparation of La(III)-AA}

Mixed amino acids were dissolved in deionized water at $25{ }^{\circ} \mathrm{C}$ to give a solution of $0.02 \mathrm{mmol} / \mathrm{mL}$ mixed amino acids. $\mathrm{La}\left(\mathrm{NO}_{3}\right)_{3} \cdot 6 \mathrm{H}_{2} \mathrm{O}$ was mixed with amino acid at different mole ratio (La(III) : amino acids were $1: 1.0,1: 1.5,1: 2.0,1: 2.5$ and $1: 3.0, \mathrm{pH}$ was 6 , temperature was $90^{\circ} \mathrm{C}$ and time was $2 \mathrm{~h}$ ). To determine the effect of $\mathrm{pH}$, temperature and time, the reaction $\mathrm{pH}$ was maintained at 5.0, 6.0, 7.0, 8.0 and 9.0 (mole ratio was $1: 2.0$, temperature was $90{ }^{\circ} \mathrm{C}$ and time was $2 \mathrm{~h}$ ), the reaction temperature was maintained at $50{ }^{\circ} \mathrm{C}, 60{ }^{\circ} \mathrm{C}, 70{ }^{\circ} \mathrm{C}, 80{ }^{\circ} \mathrm{C}$ and $90{ }^{\circ} \mathrm{C}$ (mole ratio was $1: 2.0$, $\mathrm{pH}$ was 6 and time was $2 \mathrm{~h}$ ), the time was maintained at $1 \mathrm{~h}, 2 \mathrm{~h}, 3 \mathrm{~h}, 4 \mathrm{~h}$ and $5 \mathrm{~h}$ (mole ratio was 1:2.0, pH was 6 and temperature was $90{ }^{\circ} \mathrm{C}$ ), respectively. The reaction was carried out in a thermostat water bath (HH.S21-4-S, CIMO, China). The insoluble substance was precipitated and removed by centrifugation at $10000 \mathrm{rpm}$ for 10 min at $4{ }^{\circ} \mathrm{C}$. The supernatant was concentrated until precipitation appears. Quintuple volume absolute ethanol was added to the solution to precipitate the unbound ions that eventually made La(III)-AA. The chelate was dried at $50{ }^{\circ} \mathrm{C}$ and collected for the determination of $\mathrm{La}$ (III) binding capacity and structural characterization. The yield (percent) of La(III)-AA was calculated as follows:

$$
\text { yield }(\%)=\frac{\text { amount of } L a(I I I)-A A}{S P I \text { content }+ \text { La }(N O 3) 3 \cdot 6 H 2 \text { Ocontent }} \times 100
$$

To determine the optimal conditions, nine different method according to an $\mathrm{L}_{9}\left(3^{4}\right)$ orthogonal array was included in this study and freshly prepared. The reaction temperature, time, mole ratio and $\mathrm{pH}$ value were taken as experimental factors. Each factor had three levels, and the parameter setting was shown in Online Resource 1. 
$\mathrm{La}$ (III) binding activity was determined according to the ethylenediaminetetraacetic acid (EDTA) titration method of "GB/T 14635-2008 Rare earth metals and their compounds-Determination of total rare earth contents" (National Standard of the People's Republic of China) with some modifications. The $\mathrm{La}(\mathrm{III})$ binding activity (\%) was calculated as follows:

where $\mathrm{W}$ is $\mathrm{La}(\mathrm{III})$ binding activity (\%), $\mathrm{M}_{1}$ is molar mass of $\mathrm{La}(\mathrm{III})$ after chelation $(\mathrm{g} / \mathrm{mol}), \mathrm{M}_{2}$ is the test solution $(10 \mathrm{~mL})$.

\section{Analysis of amino acid composition}

The sample $(4 \mathrm{~mL})$ was sealed in tubes under nitrogen, incubated at $110{ }^{\circ} \mathrm{C}$ for $22 \mathrm{~h}$ and diluted to 10 mL. $1 \mathrm{~mL}$ solution was evaporated to dryness by nitrogen at $95^{\circ} \mathrm{C}$, and dissolved by $1 \mathrm{~mL} 10 \mathrm{mM} \mathrm{HCl}$. cuvettes $(1 \mathrm{~cm})$. The peak signals in the spectra were analyzed by Origin 9.0 software. Amino acids were determined after derivatization with amino acid and o-phthalaldehyde (OPA) and amino acid and fluorene methoxycarbonyl chloride (FMOC) by HPLC, according to the method of Agilent Technologies Inc. The HPLC system consisted of Agilent 1100 liquid chromatograph with a DAD detector equipped with a ZORBAX Eclipse AAA $(4.6 \times 75 \mathrm{~mm}, 3.5 \mu \mathrm{m})$. A binary gradient was used for elution with a flow of $1.0 \mathrm{~mL} / \mathrm{min}$. The solvents used were (A) $40 \mathrm{mM}$ sodium dihydrogen phosphate (pH 7.8) and (B) acetonitrile/methanol/water (45/45/10). Elution was as follows: time, $0.0-1.0$ min; elution with A/B (100/0); 1.0-27.0 min, elution with A/B (46/57); 27.0-40.0 min, elution with A/B (0:100); 40.0-41.0 min; elution with A/B (100/0).

\section{Ultraviolet-visible spectroscopy (UV-vis)}

The chelate was dissolved in deionized water to obtain a concentration of $1 \mathrm{mg} / \mathrm{mL}$. The UV-vis absorption measurements of the solutions were performed on a UV-visible spectrophotometer (T1901, Shimadzu, Japan) at room temperature $\left(25 \pm 1{ }^{\circ} \mathrm{C}\right)$. Prior to measurement, the baseline was set with deionized water. The spectra were recorded by scanning the wavelength from 250 to $400 \mathrm{~nm}$ with quartz

\section{Fourier transform infrared spectroscopy (FTIR)}

An FTIR spectrophotometer (Thermo Fisher IS5) was used in the experiment to obtain the FTIR spectra 
from mixed amino acid and La(III)-AA. All spectra were recorded within a range from 400 to $4000 \mathrm{~cm}^{-1}$ with $4 \mathrm{~cm}^{-1}$ resolution and 32 scans. All measurements were performed in a dry atmosphere at room temperature $\left(25 \pm 1^{\circ} \mathrm{C}\right)$. The results were presented in transmittance units.

\section{Energy dispersive spectroscopy (EDS) and scanning electron microscope (SEM)}

149 The elemental analysis of La(III)-AA was measured on an energy dispersive spectroscopy (EDS), which was performed on a scanning electron microscope (SIGMA HD, Germany). The morphology of La(III)-

151 AA was observed on a scanning electron microscope (SEM), which was performed on a scanning electron microscope (SIGMA HD, Germany).

\section{Transmission electron microscope (TEM)}

TEM images were obtained on a Transmission electron microscope (JEM 2100, Japan) operated at an accelerating voltage of $200 \mathrm{kV}$. Samples were dispersed by alcohol.

\section{Measurement of rice growth}

Rice (Oryza sativa L. subsp. Japonica cv. Suxiang 3) was grown for a period of 14 days under hydroponic culture. $\mathrm{Cu}$ (II) stress was simulated by $50 \mathrm{mg} / \mathrm{L} \mathrm{CuSO}_{4}$. The rice seedlings were treated by $50 \mathrm{mg} / \mathrm{L}$ $\mathrm{CuSO}_{4}$ and $20 \mathrm{mg} / \mathrm{L} \mathrm{La}\left(\mathrm{NO}_{3}\right)_{3}-\mathrm{AA}$ or $\mathrm{La}\left(\mathrm{NO}_{3}\right)_{3}$ solution respectively. The group without $\mathrm{Cu}(\mathrm{II})$ stress was used as control. Growth was measured in terms of the quantity of shoot, root and chlorophyll content 1-7 days after treatment. Chlorophyll content was detected by chlorophyll meter (SPAD-502).

\section{Statistical analysis}

The experiments were performed in triplicate, and values are expressed as mean \pm standard error (SD). All data were subjected to analysis of variance (ANOVA), and the differences between means were evaluated by Duncan's multiple range test.

\section{Results and discussion}

\section{Effect of temperature, time, mole ratio and pH on La(III) binding capacity}

SPI was hydrolyzed by serine protease to form mixed amino acids. These amino acids could combine with $\mathrm{La}$ (III) to form chelate (Zhu et al. 2015). However, there were many factors restricting the chelating effect. It is necessary to further discuss the optimal condition to achieve the high chelating rate. The La(III) binding capacity was chosen as a fundamental parameter for monitoring the chelating reaction. The effects of temperature, time, mole ratio and $\mathrm{pH}$ on $\mathrm{La}(\mathrm{III})$ binding capacity of mixed amino acids were shown in Fig. 1. A typical inverted U-shaped curve obtained under experimental conditions showed the highest $\mathrm{La}$ (III) binding capacity for the $60{ }^{\circ} \mathrm{C}$ (Fig. 1A). Since the chelation was exothermic, 

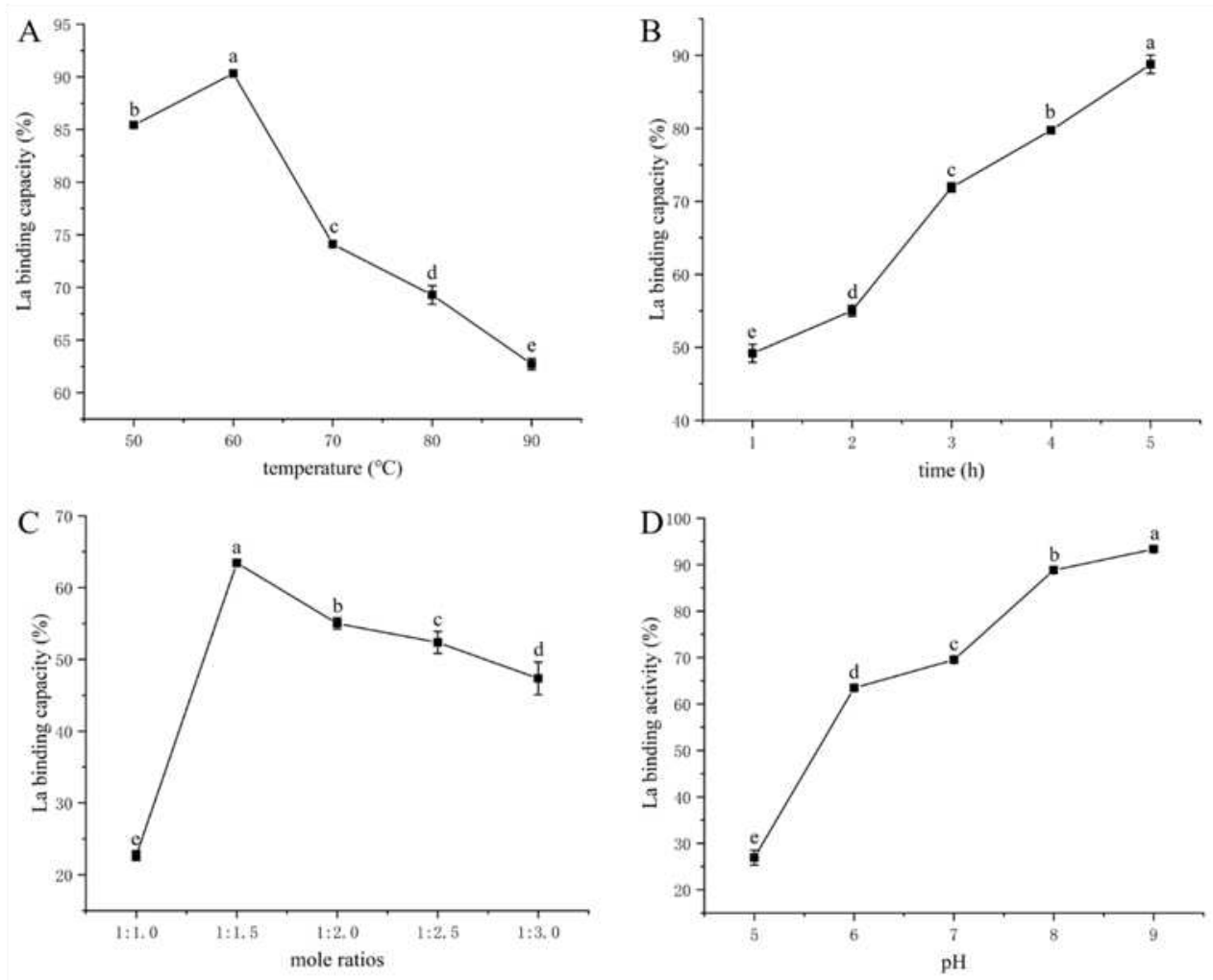

Fig. 1. Effects of different factors on the La(III) binding activity. (A) temperature. (B) time. (C) mole ratio. (D) $\mathrm{pH}$. Results represent the means of three determinations \pm standard deviation. Different letters represent significant differences between the data $(\mathrm{P}<0.05)$.

The mole ratio was an important parameter in chelation and played an important role in the La(III) binding capacity. The content of amino acid was too small to combine with lanthanum(III) completely, too much to still a surplus, which caused unnecessary consumption. When mole ratio was $1: 1.5$, the La(III) binding capacity reached the maximum value of $63.45 \%$ (Fig. 1B). With the increase of mole ratio, the binding capacity of $\mathrm{La}(\mathrm{III})$ became lower.

The La(III) binding capacity of mixed amino acids gradually increased with time and $\mathrm{pH}$, and reached maximum values of $88.78 \%$ and $93.33 \%$, respectively (Fig. $1 \mathrm{C}, \mathrm{D})$. When the $\mathrm{pH}$ was low (5-6), the solution was acidic and contained a lot of $\mathrm{H}(\mathrm{I})$. Since $\mathrm{H}(\mathrm{I})$ and $\mathrm{La}(\mathrm{III})$ could combine with electrondonating groups, they were in a competitive relationship, which was not conducive to the chelation, resulting in low chelation rate (Rombach et al. 2002). After comprehensive consideration of economic factors, the time was chosen as $5 \mathrm{~h}$ and the $\mathrm{pH}$ was 8 . 

optimal condition. The result was shown in the Online Resource 2 and the optimum condition was as follows: $\mathrm{La}\left(\mathrm{NO}_{3}\right)_{3} \cdot 6 \mathrm{H}_{2} \mathrm{O}$ was mixed with amino acid at mole ratio of $1: 1.5$, pH value was 8.0, temperature was $50{ }^{\circ} \mathrm{C}$ and time was maintained at $5 \mathrm{~h}$.

\section{UV-visible spectra}

The formation of chelate can lead to the appearance of new absorbance peaks or shifting/disappearance of pre-existing ones (Liu et al. 2013). Fig. 2A showed the UV-vis absorption spectra of the mixed amino $\mathrm{n} \rightarrow \pi^{*}$ transition of $\mathrm{C}=\mathrm{O}$ in the peptide bond (Yu \&Fan 2012). Compared to amino acids, the absorption wavelength of $\mathrm{La}(\mathrm{III})-\mathrm{AA}$ is $273 \mathrm{~nm}$ and the peak height decreases. The detected decrease in the absorption and a hypochromatic shift of the absorption maximum showed an interaction between amino acids and $\mathrm{La}(\mathrm{III})$, which indicated that the formation of chelate changes the optical absorption performance of the ligand.
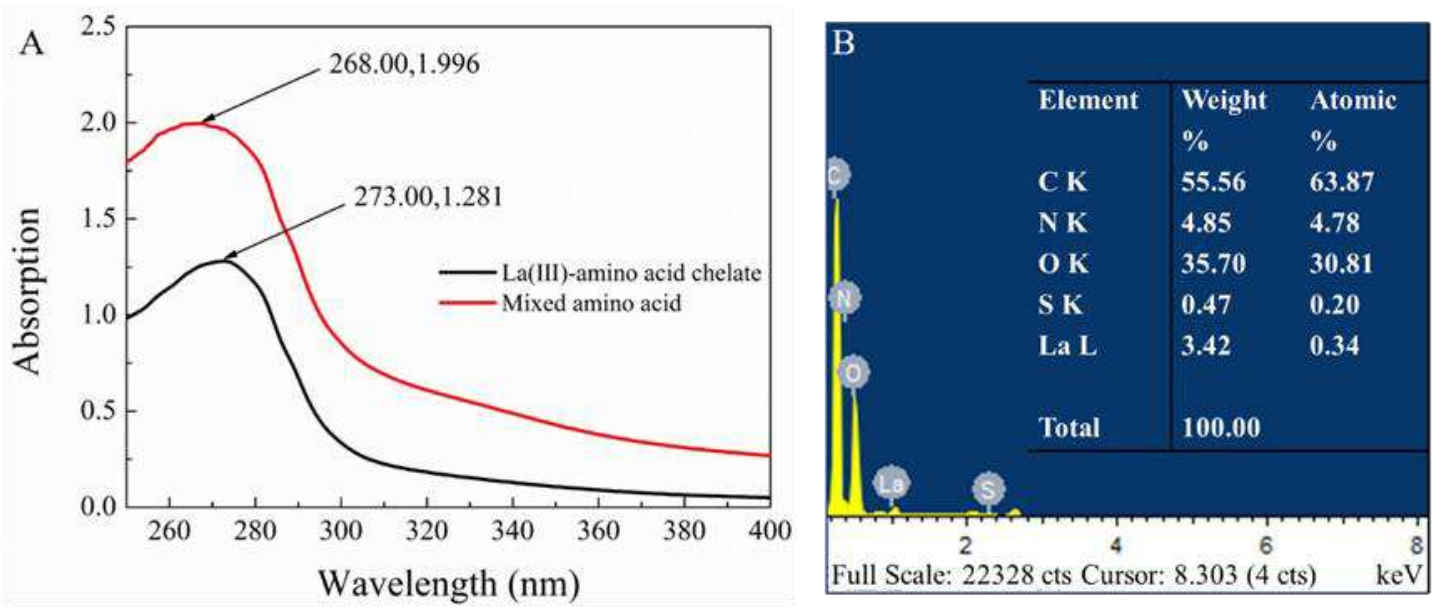

Fig. 2. (A) UV-vis spectroscopy of mixed amino acid and La(III)-AA. (B) SEM-EDS result of La(III)AA.

\section{Energy dispersive spectroscopy and scanning electron microscope}

211 The EDS analytical technique was applied for the elemental analysis and chemical characterization of 212 La(III)-AA. The results prove the presence of carbon, nitrogen, oxygen, sulfur and lanthanum in the 213 La(III)-AA (Fig. 2B), which confirmed an effective binding between La(III) and amino acids. After 214 chelation, due to changes in the electronic structure and chemical bond, the apparent structure would also 215 change. In Fig. 3A, round-shaped particles (La(III) aggregate) were observed with diameter 80-100 nm. 

acid.
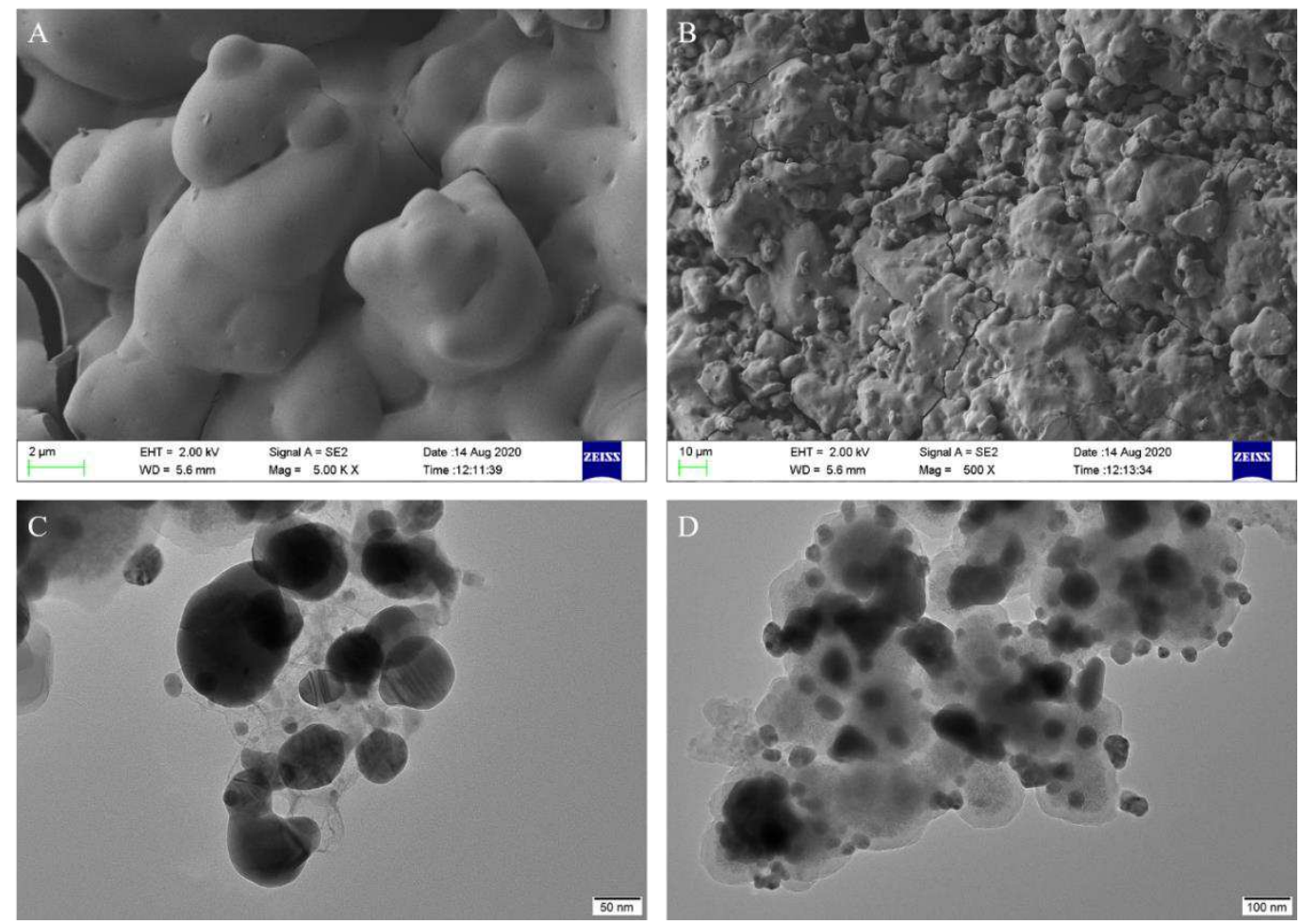

Fig. 3. SEM images (A $2 \mu \mathrm{m}, \mathrm{B} 10 \mu \mathrm{m})$ and TEM images (C $50 \mathrm{~nm}, \mathrm{D} 100 \mathrm{~nm})$ of La(III)-AA.

\section{Transmission electron microscope}

Particle size is a crucial parameter determining particle properties(Wang et al. 2016). To investigate the morphologies of the La(III)-AA, TEM test was carried out. As shown in Fig. 3 (C,D), the particles were uniform and complete, and the partial agglomeration of the particles may be caused by the lack of uniform dispersion during preparation. From the density and color depth, it could be seen that the material presents an obvious core-shell type morphology (Zhang et al. 2007), the darker part was La(III) aggregate. The aggregate was surrounded by a semitransparent layer (amino acid), appears approximate spherical in shape with a mean diameter in the range of $60-80 \mathrm{~nm}$. This proved that amino acids successfully bind to the surface of $\mathrm{La}(\mathrm{III})$.

\section{Fourier transform infrared spectroscopy}

231 Fig. 4 showed the IR spectrum of mixed amino acid and La(III)-AA. In the spectra of mixed amino acid, a strong feature at $3019 \mathrm{~cm}^{-1}$ was dominant, which was attributed to a $\mathrm{N}-\mathrm{H}$ stretching vibration and moved to $2987 \mathrm{~cm}^{-1}$ in $\mathrm{La}(\mathrm{III})-\mathrm{AA}$. The characteristic absorption peak of $\mathrm{C}=\mathrm{O}$ in mixed amino acid was 

amino acid were $1643 \mathrm{~cm}^{-1}, 1421 \mathrm{~cm}^{-1}, 1358 \mathrm{~cm}^{-1}$, and moved to $1594 \mathrm{~cm}^{-1}, 1410 \mathrm{~cm}^{-1}, 1349 \mathrm{~cm}^{-1}$ after chelating with $\mathrm{La}(\mathrm{III})$. In the low-wavenumber region of spectrum, several obvious features were observed, which were attributed to the vibration of C-O and C-N. The results of IR analysis showed that $\mathrm{N}$ and $\mathrm{O}$ atoms formed coordination bonds with $\mathrm{La}(\mathrm{III})$ and participated in the formation of chelates.
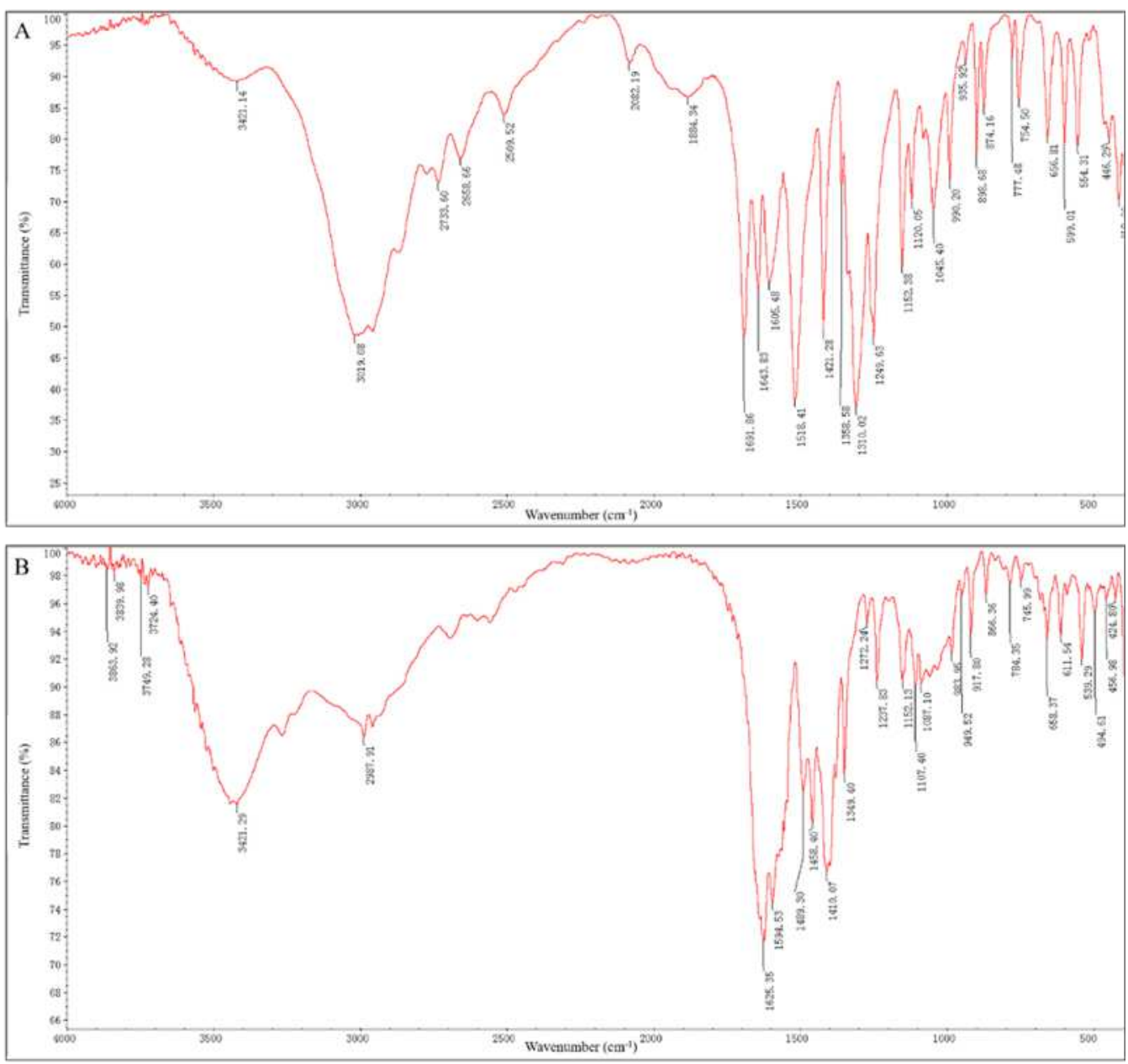

Fig. 4. FTIR spectra of mixed amino acid and La(III)-AA. (A) mixed amino acid, (B) La(III)-AA.

\section{Amino acid analysis}

Table 1 showed amino acid composition of SPI Hydrolysates and La(III)-AA. There were 17 kinds of amino acids in the hydrolysate. Amino acids derived from hydrolysis of SPI showed the highest content in glutamate, representing $17.52 \%$ of total amino acids. After chelation, the highest proportion of amino acids was still glutamate (12.72\%). A total of 12 types of amino acids account for more than $5 \%$, and the content of proline increased from $5.71 \%$ to $10.26 \%$.

Table 1. Percent Amino Acid Composition of SPI Hydrolysates and La(III)-AA 


\begin{tabular}{lllllll} 
& $\mu \mathrm{mol} / \mathrm{ml}$ & $\mathrm{mg} / \mathrm{ml}$ & $\%$ & $\mu \mathrm{mol} / \mathrm{ml}$ & $\mathrm{mg} / \mathrm{ml}$ & $\%$ \\
\hline Asp & 6.60 & 0.88 & 11.30 & 2.22 & 0.30 & 8.38 \\
Glu & 10.24 & 1.51 & 17.52 & 3.37 & 0.50 & 12.72 \\
Ser & 3.93 & 0.41 & 6.72 & 1.60 & 0.17 & 6.05 \\
His & 0.89 & 0.14 & 1.52 & 0.71 & 0.11 & 2.68 \\
Gly & 3.57 & 0.27 & 6.10 & 1.95 & 0.15 & 7.36 \\
Thr & 2.78 & 0.33 & 4.76 & 0.99 & 0.12 & 3.73 \\
Arg & 2.85 & 0.50 & 4.87 & 1.45 & 0.25 & 5.46 \\
Ala & 3.68 & 0.33 & 6.30 & 1.71 & 0.15 & 6.45 \\
Tyr & 1.61 & 0.29 & 2.76 & 0.04 & 0.01 & 0.14 \\
Cys & 3.94 & 0.48 & 6.74 & 1.59 & 0.19 & 6.01 \\
Val & 2.91 & 0.34 & 4.99 & 1.42 & 0.17 & 5.37 \\
Met & 0.00 & 0.00 & 0.00 & 0.00 & 0.00 & 0.00 \\
Phe & 2.66 & 0.44 & 4.56 & 1.61 & 0.27 & 6.08 \\
Ile & 2.49 & 0.33 & 4.26 & 1.19 & 0.16 & 4.50 \\
Leu & 4.76 & 0.62 & 8.14 & 2.38 & 0.31 & 8.98 \\
Lys & 2.20 & 0.32 & 3.76 & 1.54 & 0.23 & 5.82 \\
Pro & 3.34 & 0.38 & 5.71 & 2.72 & 0.31 & 10.26 \\
Total & 58.44 & 7.57 & 100.00 & 26.47 & 3.38 & 100.00 \\
\hline
\end{tabular}

\section{Estimated chemical structure of La(III)-AA}

250 The results of FTIR and amino acid analysis showed that $\mathrm{N}$ atom of amino group and $\mathrm{O}$ atom of carboxyl

251 group could combine with $\mathrm{La}(\mathrm{III})$. In addition, comparing the structure of 12 dominating amino acids

252 (account for more than 5\%), we found that there was a common structure (2- $\alpha$-aminoacetate group) on 253 these 12 amino acids. According to the study of Mautner et al., chelated La(III) might have eight 254 coordination number (Mautner et al. 2020). Based on these, there might be a general structure for the 255 chelation of amino acids with $\mathrm{La}(\mathrm{III})$. The possible configuration of $\mathrm{La}(\mathrm{III})-\mathrm{AA}$ was plotted by Chem 256 draw 18.1 (Fig. 5). In Fig. 5A, amino acids combined with $\mathrm{La}$ (III) to form a stable five-membered ring 257 structure, which was consistent with the spatial structure of amino acids. $\mathrm{N}$ atom of amino group and $\mathrm{O}$ 258 atom of carboxyl group formed coordination bonds with $\mathrm{La}(\mathrm{III})$, and $\mathrm{R}$ represented amino acid residue. 

coordination with $\mathrm{La}(\mathrm{III}), 4$ glutamate were mainly chelated with La(III). In Fig. 5B, since the carboxyl group at both ends of the glutamate chain were separated by several $\mathrm{C}$ atoms, the $\mathrm{O}$ atom of carboxyl group were more likely to bind to La(III). And in Fig. 5C, N and $\mathrm{O}$ atoms combined with La(III).
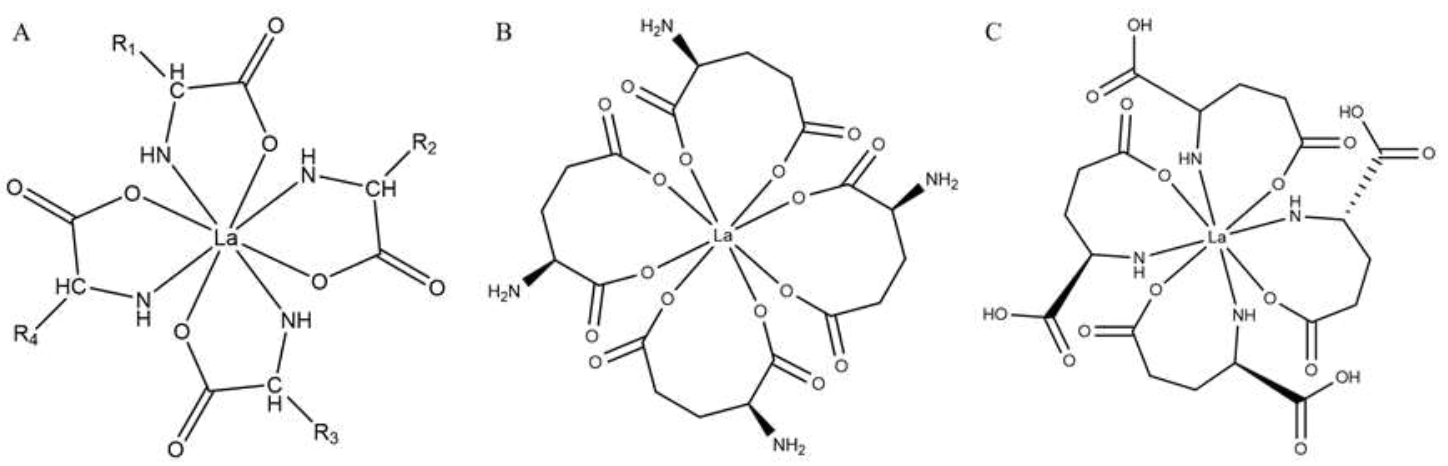

263

Fig. 5. Estimated chemical structure of La(III)-AA. (A) General structure of La(III)-AA; (B) The first speculative structure of La(III)-Glu; (C) The second speculative structure of La(III)-Glu.

In summary, UV-vis and FTIR spectra of mixed amino acid and La(III)-AA showed that after amino acid was combined with $\mathrm{La}(\mathrm{III})$, the characteristic absorption peak was clearly shifted, indicating that amino acid had a reaction with $\mathrm{La}(\mathrm{III}) . \mathrm{C}=\mathrm{O}$ and $\mathrm{COO}$ - wavenumbers were displaced, indicating that amino nitrogen atoms and oxygen atoms were involved in complexation. Furthermore, La(III) aggregate was well-dispersed in the mixed amino acid in the SEM and TEM experiment, which was also a good proof of the formation of chelates. Finally, the general configuration of La(III)-AA and two configurations of La(III)-Glu were speculated based on amino acid analysis and FTIR.

\section{Measurement of rice growth}

We first evaluated the effect of $\mathrm{La}\left(\mathrm{NO}_{3}\right)_{3}$ and $\mathrm{La}$ (III)-AA chelates on growth of rice under $\mathrm{Cu}(\mathrm{II})$ stress (Fig. 6). Rice exposed to $\mathrm{Cu}(\mathrm{II})$ resulted in toxicity symptoms such as stunted growth and chlorosis in leaves. Compared to control group, plant growth indices were all hindered by $50 \mathrm{mg} / \mathrm{L} \mathrm{Cu}$ (II) stress. At 7 days, leaf length, root length and chlorophyll content were inhibited by $39.95 \%, 46.77 \%$ and $47.83 \%$, respectively. A series of studies published within the last two decades demonstrated a substantial and significant occurrence of La-induced hormesis in plants, which stimulate the growth, and enhance the tolerance to heavy metal stress (Agathokleous et al. 2018, Liu et al. 2016b, Wang et al. 2012). The leaf length subjected to the $20 \mathrm{mg} / \mathrm{L} \mathrm{La(III)-AA}$ was significantly higher vs. other treatments in leaves (Fig. 6B). $\mathrm{La}\left(\mathrm{NO}_{3}\right)_{3}$ even aggravated the toxicity of $\mathrm{Cu}(\mathrm{II})$. As showed in Fig. 6C, compared to $\mathrm{Cu}$ (II) stress, $20 \mathrm{mg} / \mathrm{L} \mathrm{La}(\mathrm{III})-\mathrm{AA}$ significantly increased the root length by $32.55 \%$, whereas $\mathrm{La}\left(\mathrm{NO}_{3}\right)_{3}$ increased 

$\mathrm{La}(\mathrm{III})$-AA might alleviate the severe oxidative damage induced by $\mathrm{Cu}(\mathrm{II})$ in leaf cell. Based on this, we suggested that appropriate $\mathrm{La}$ (III)-AA could be used as an additive of agricultural fertilizer to protect the plant growth.
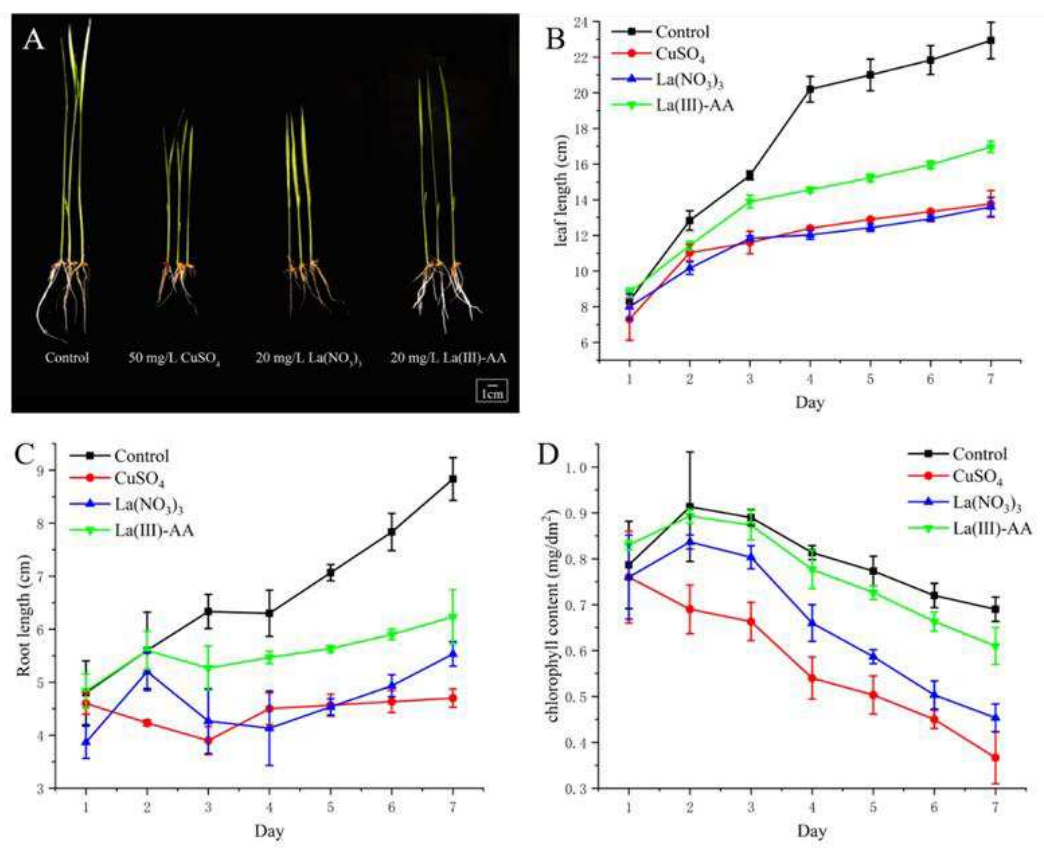

Fig. 6. Effects of $\mathrm{La}\left(\mathrm{NO}_{3}\right)_{3}$ and $\mathrm{La}(\mathrm{III})-\mathrm{AA}$ on growth indices of $\mathrm{Cu}$ (II)-stressed rice seedlings. (A) $\mathrm{Cu}$ (II)-stressed rice seedlings with $\mathrm{La}\left(\mathrm{NO}_{3}\right)_{3}$ or $\mathrm{La}$ (III)-AA treatment; (B) Leaf length; (C) Root length;

(D) Chlorophyll content

\section{Conclusion}

This study synthesized a Lanthanum-amino acid complex from enzymatic hydrolysis of soybean protein.

Primary La(III)-binding ligands were determined and chemical structure of $\mathrm{La}(\mathrm{III})-\mathrm{AA}$ was speculated. Relative to $\mathrm{La}\left(\mathrm{NO}_{3}\right)_{3}$, the $\mathrm{La}(\mathrm{III})-\mathrm{AA}$ could more effectively ameliorate $\mathrm{Cu}$ stress in rice. Therefore, this study has provided a novel candidate of REE-based fertilizer for crop protection. The findings will open up the possibility of application of $\mathrm{La}(\mathrm{III})-\mathrm{AA}$ chelates in crop protection, and also will advance our knowledge of REE-induced amelioration in heavy metal stress.

\section{Availability of data and materials}

301 The datasets used and/or analysed during the current study are available from the corresponding author on reasonable request. 
304 Yuqing Zhong: Investigation, Formal analysis, Writing - original draft.

305 Jiajia Chen: Idea, Writing, Supervision.

\section{$306 \quad$ Funding}

307 This work was supported by the National Natural Science Foundation of China (Grant 31770903),

308 Technology R\&D Program of Suzhou (Grant SNG201905), and Qinglan Project of Jiangsu Province.

\section{Declarations}

310 Ethics approval and consent to participate

$311 \quad$ Not applicable

312 Consent for publication

313 Not applicable

314 Competing interests

315 The authors declare that they have no competing interests.

316

317 Supplementary Information

318 Online Resource 1: Parameter setting of orthogonal design

319 Online Resource 2: Results of orthogonal design. 


\section{References}

Agathokleous E, Kitao M, Calabrese EJ (2018): The rare earth element (REE) lanthanum (La) induces hormesis in plants. Environ Pollut 238, 1044-1047

Bao XL, Song M, Zhang J, Chen Y, Guo ST (2007): Calcium-binding ability of soy protein hydrolysates. Chinese Chem Lett 18, 1115-1118

Cheng MQ, Ma LF, Wang LY (2007): Synthesis, crystal structures and properties of two novel $\mathrm{Co}(\mathrm{II})$ and $\mathrm{Cd}(\mathrm{II})$ complexes of N-acetyl-L-glutamic acid and imidazole ligands. Chinese J Chem 25, 498-502

Dai H, Shan C, Zhao H, Jia G, Chen D (2017): Lanthanum improves the cadmium tolerance of Zea mays seedlings by the regulation of ascorbate and glutathione metabolism. Biol Plantarum 61, 551-556

Dong XL, Lu AH, He B, Li WC (2016): Highly microporous carbons derived from a complex of glutamic acid and zinc chloride for use in supercapacitors. J Power Sources 327, 535-542

Friedman M, Brandon DL (2001): Nutritional and health benefits of soy proteins. J Agr Food Chem 49, 1069-1086

Gao M, Zhou J, Liu H, Zhang W, Hu Y, Liang J, Zhou J (2018): Foliar spraying with silicon and selenium reduces cadmium uptake and mitigates cadmium toxicity in rice. Sci Total Environ 631-632, 1100-1108

Habibi G (2017): Selenium Ameliorates Salinity Stress in Petroselinum crispum by Modulation of Photosynthesis and by Reducing Shoot Na Accumulation. Russ J Plant Physl+ 64, 368-374

Huang GY, Shan CJ (2018): Lanthanum improves the antioxidant capacity in chloroplast of tomato seedlings through ascorbate-glutathione cycle under salt stress. Scientia Horticulturae 232, 264-268

Jin DH, Zhang YZ, Suzuki Y, Naganuma T, Ogawa T, Hatakeyama E, Muramoto K (2000): Inhibitory effect of protein hydrolysates on calcium carbonate crystallization. J Agr Food Chem 48, 5450-5454

Leibler D, Rabinkov A, Wilchek M (1996): Salicylaldehyde-metal-amino acid ternary complex: A new tool for immobilized metal affinity chromatography. J Mol Recognit 9, 375-382

Li LY, Zhang X, Ning ZB, Mayne J, Moore JI, Butcher J, Chiang CK, Mack D, Stintzi A, Figeys D (2018): Evaluating in Vitro Culture Medium of Gut Microbiome with Orthogonal Experimental Design and a Metaproteomics Approach. J Proteome Res 17, 154-163

Lin L, Zhou W, Dai H, Cao F, Zhang G, Wu F (2012): Selenium reduces cadmium uptake and mitigates cadmium toxicity in rice. J Hazard Mater 235-236, 343-51

Liu D, Zheng S, Wang X (2016a): Lanthanum regulates the reactive oxygen species in the roots of rice seedlings. Sci Rep 6, 31860

Liu FR, Wang L, Wang R, Chen ZX (2013): Calcium-Binding Capacity of Wheat Germ Protein Hydrolysate and Characterization of Peptide-Calcium Complex. J Agr Food Chem 61, 7537-7544

Liu RQ, Xu XJ, Wang S, Shan CJ (2016b): Lanthanum improves salt tolerance of maize seedlings. Photosynthetica 54, 148-151 
Mautner FA, Bierbaumer F, Gyurkac M, Fischer RC, Torvisco A, Massoud SS, Vicente R (2020): Synthesis and characterization of Lanthanum(III) complexes containing 4, 4, 4-trifluoro-1-(naphthalen-2y1) butane-1, 3-dionate. Polyhedron 179

Megias C, Pedroche J, Yust MM, Giron-Calle J, Alaiz M, Millan F, Vioque J (2007): Affinity purification of copper-chelating peptides from sunflower protein hydrolysates. J Agr Food Chem 55, 6509-6514

Mirzakhani MK, Kenari AA, Motamedzadegan A (2018): Prediction of apparent protein digestibility by in vitro $\mathrm{pH}^{-}$stat degree of protein hydrolysis with species-specific enzymes for Siberian sturgeon (Acipenser baeri, Brandt 1869). Aquaculture 496, 73-78

Neuman NI, Franco VG, Ferroni FM, Baggio R, Passeggi MCG, Rizzi AC, Brondino CD (2012): Single Crystal EPR of the Mixed-Ligand Complex of Copper(II) with L-Glutamic Acid and 1, 10-Phenanthroline: A Study on the Narrowing of the Hyperfine Structure by Exchange. J Phys Chem A 116, 12314-12320

Pal S, Das M, Naskar K (2019) : Exploring Copper - Amino Acid Complexes in CrossLinking of Maleated Ethylene Propylene Rubber. Industrial \& Engineering Chemistry Research 58, 17802-17813

Perez A, Madden W, Hernandez L, Del Carpio E, Lubes V (2017): Stability constants of the ternary nickel(II) complexes with salicylic acid and selected amino acids. J Mol Liq 233, 288-291

Rizzo G, Baroni L (2018): Soy, Soy Foods and Their Role in Vegetarian Diets. Nutrients 10

Rombach M, Gelinsky M, Vahrenkamp H (2002): Coordination modes of aminoacids to zinc. Inorg Chim Acta 334, 25-33

Wang CR, Luo X, Tian Y, Xie Y, Wang SC, Li YY, Tian LM, Wang XR (2012): Biphasic effects of lanthanum on Vicia faba L. seedlings under cadmium stress, implicating finite antioxidation and potential ecological risk. Chemosphere 86, 530-537

Wang CR, Wang QY, Tian Y, Zhang JF, Li ZX, Cao P, Zhu M, Li TT (2014): Lanthanum ions intervened in enzymatic production and elimination of reactive oxygen species in leaves of rice seedlings under cadmium stress. Environ Toxicol Chem 33, 1656-64

Wang HQ, Cheng F, Shen W, Cheng G, Zhao J, Peng W, Qu JP (2016): Amino acid-based anti-fouling functionalization of silica nanoparticles using divinyl sulfone. Acta Biomater 40, 273-281

Wen K, Liang C, Wang L, Hu G, Zhou Q (2011): Combined effects of lanthanum ion and acid rain on growth, photosynthesis and chloroplast ultrastructure in soybean seedlings. Chemosphere 84, 601-8

Wu HH, Liu ZY, Zhao YH, Zeng MY (2012): Enzymatic preparation and characterization of iron-chelating peptides from anchovy (Engraulis japonicus) muscle protein. Food Res Int 48, 435-441

Yu YY, Fan DD (2012): Characterization of the Complex of Human-like Collagen with Calcium. Biol Trace Elem Res 145, 33-38 
Zhang YP, Lee SH, Reddy KR, Gopalan AI, Lee KP (2007): Synthesis and characterization of core-shell Si02 nanoparticles/poly(3-aminophenylboronic acid) composites. J Appl Polym Sci 104, 2743-2750

Zhao TH, Zhang ZY, Wang Y, Cao XK (2014): Effects of Lanthaum on Active Oxygen Metaboism in Soybean. Advanced Materials Research 955-959, 348-351

Zhu KX, Wang XP, Guo XN (2015): Isolation and characterization of zinc-chelating peptides from wheat germ protein hydrolysates. J Funct Foods 12, 23-32 
Figures
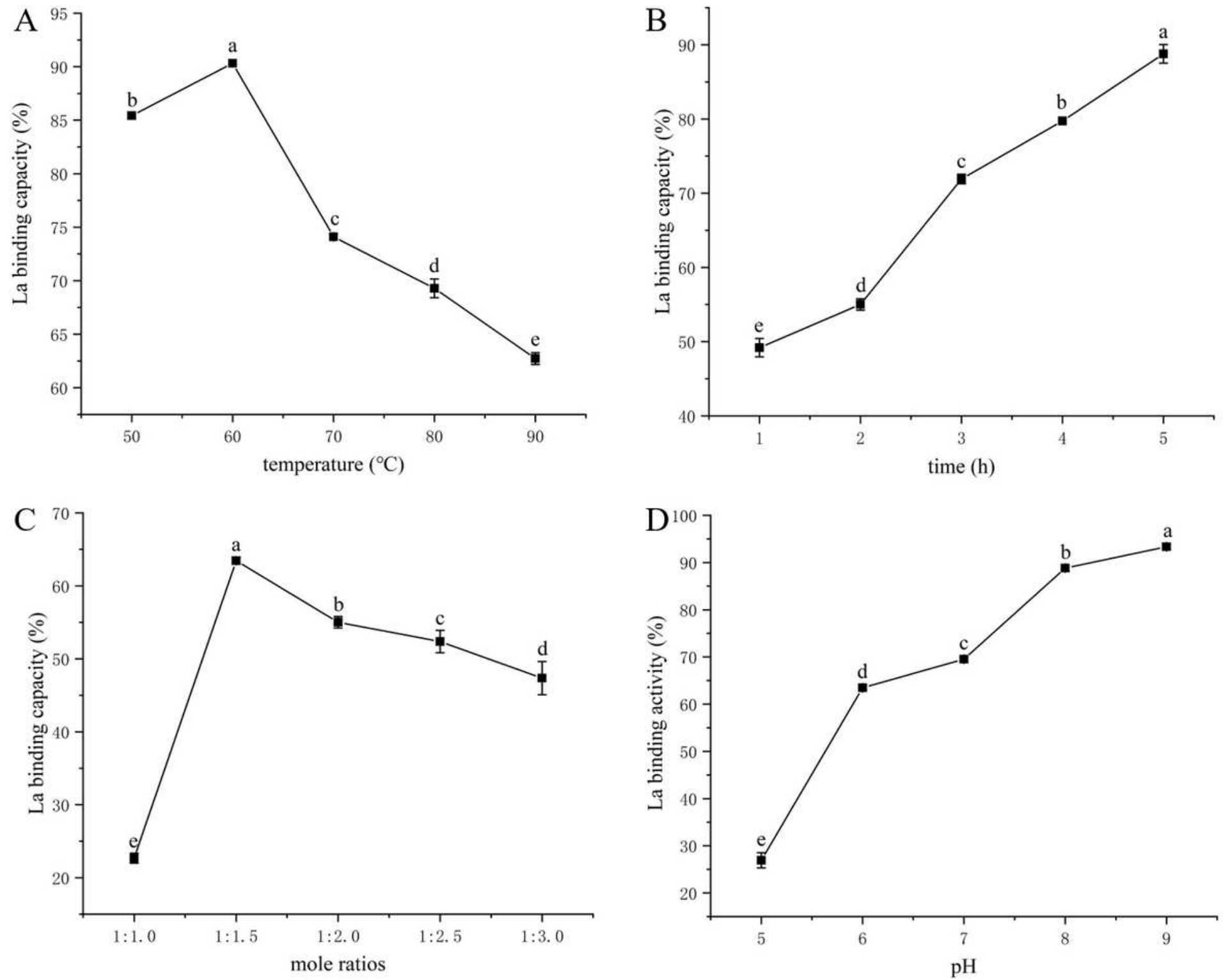

\section{Figure 1}

Effects of different factors on the $\mathrm{La}(\mathbb{\nabla})$ binding activity. (A) temperature. (B) time. (C) mole ratio. (D) pH. Results represent the means of three determinations \pm standard deviation. Different letters represent significant differences between the data $(P<0.05)$. 

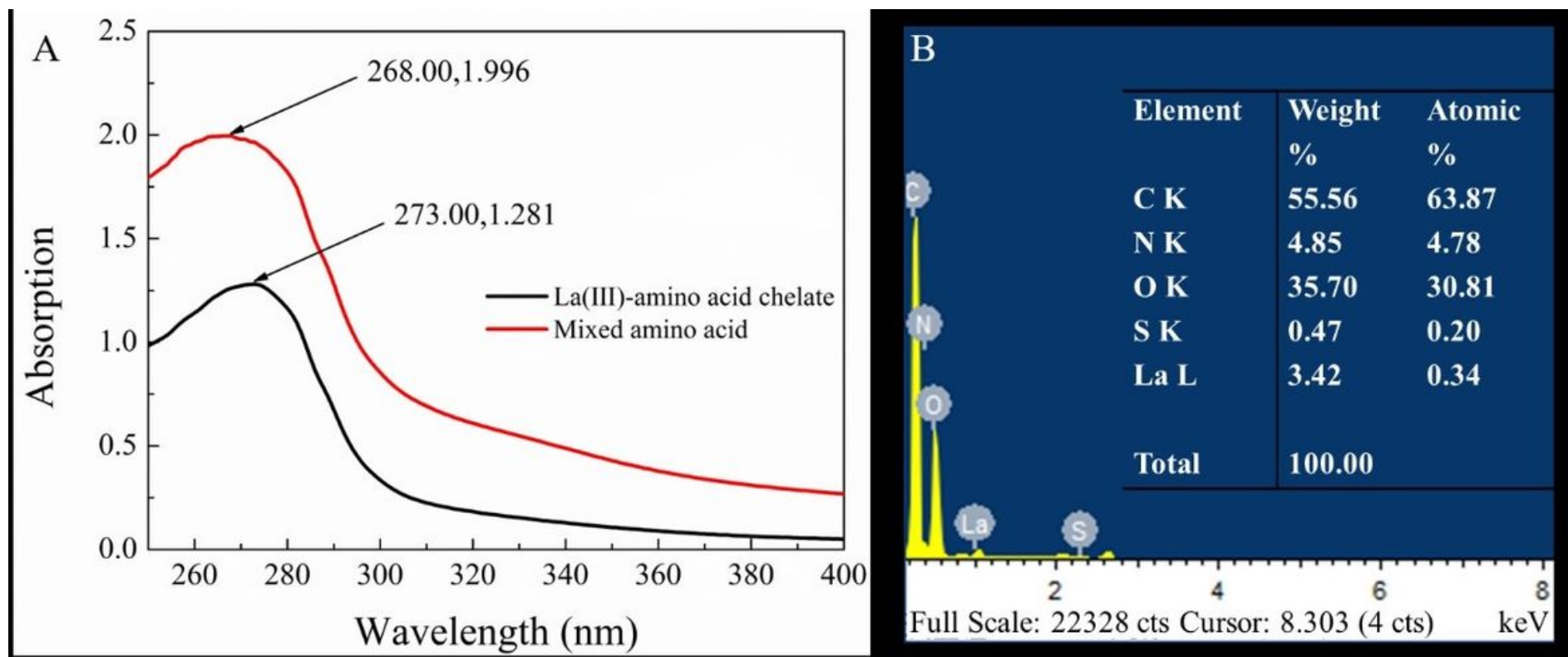

Figure 2

(A) UV-vis spectroscopy of mixed amino acid and La(囚)-AA. (B) SEM-EDS result of La(囚)-AA.
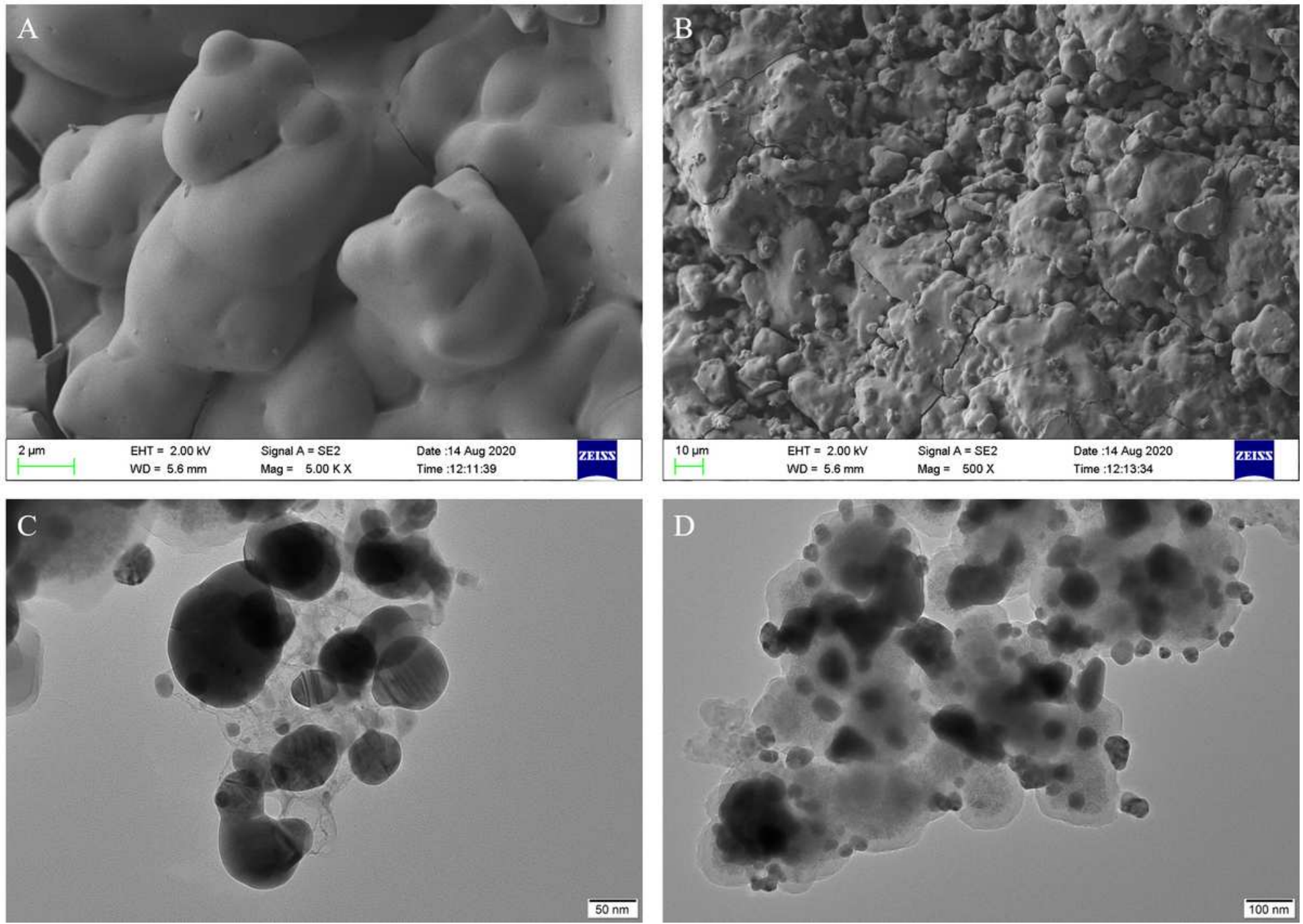

Figure 3 
SEM images (A $2 \mu \mathrm{m}, \mathrm{B} 10 \mu \mathrm{m}$ ) and TEM images (C $50 \mathrm{~nm}$, D 100nm) of La(囚)-AA.
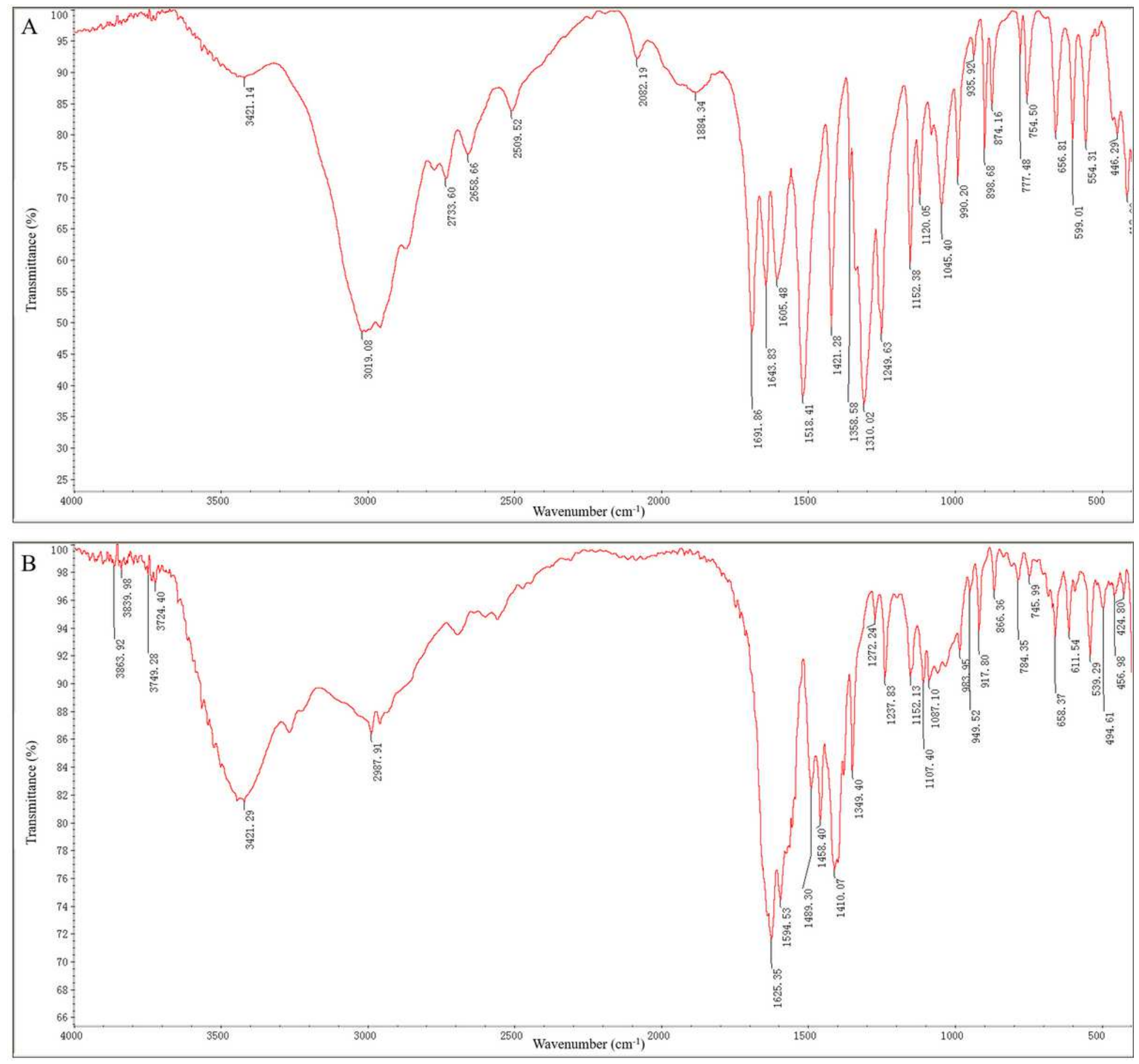

\section{Figure 4}

FTIR spectra of mixed amino acid and $\mathrm{La}(\mathbb{(})$-AA. (A) mixed amino acid, (B) La( $(\mathbb{X})$-AA. 

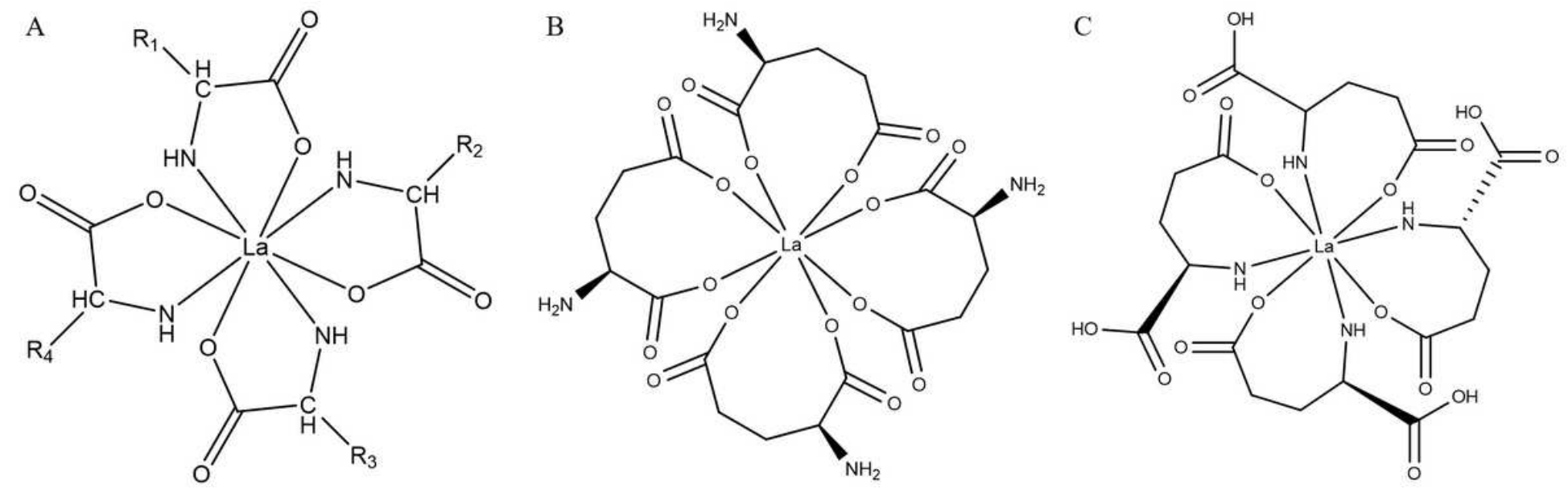

Figure 5

Estimated chemical structure of $\mathrm{La}(\mathbb{\nabla})-\mathrm{AA}$. (A) General structure of $\mathrm{La}(\mathbb{\nabla})-\mathrm{AA} ;(\mathrm{B})$ The first speculative

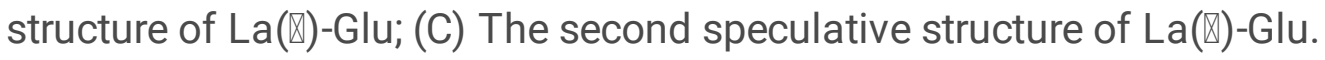
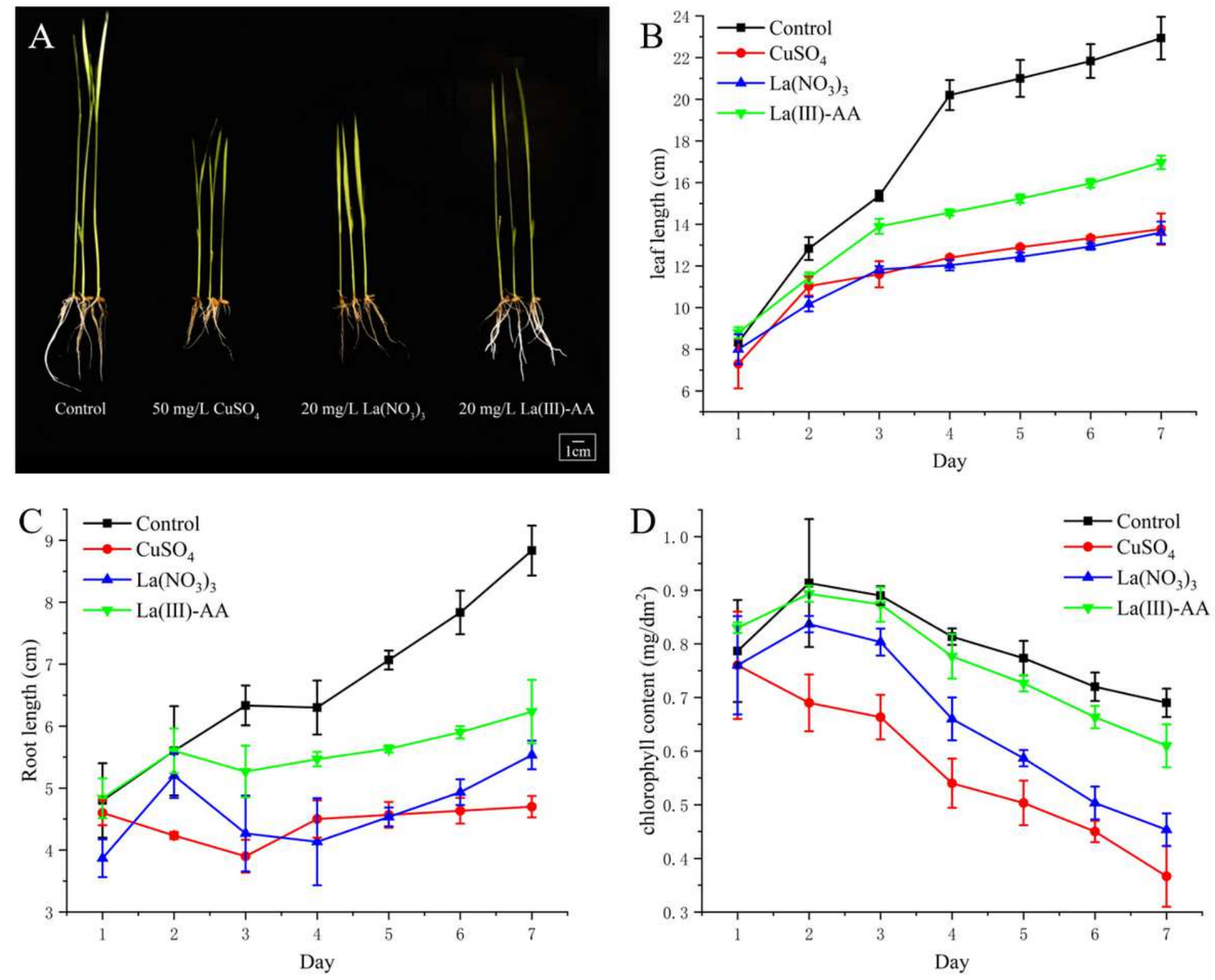
Figure 6

Effects of $\mathrm{La}(\mathrm{NO} 3) 3$ and $\mathrm{La}(\mathbb{})-\mathrm{AA}$ on growth indices of $\mathrm{Cu}(\mathrm{II})$-stressed rice seedlings. (A) $\mathrm{Cu}(\mathrm{II})$-stressed rice seedlings with $\mathrm{La}(\mathrm{NO3}) 3$ or $\mathrm{La}(\mathbb{\nabla})$-AA treatment; (B) Leaf length; (C) Root length; (D) Chlorophyll content

\section{Supplementary Files}

This is a list of supplementary files associated with this preprint. Click to download.

- ESM1.docx

- ESM2.docx 